\title{
Harmonious Society and Ecological Civilization: The concepts' relationship
}

\author{
O.B. Balchindorzhieva ${ }^{1, \mathrm{a}}$, D.Sh. Tsyrendorzhieva ${ }^{1}$ \\ ${ }^{1}$ Buryat State University, 670000 Smolina str., 24a, Ulan-Ude, Russia
}

\begin{abstract}
The paper discusses a conceptual basis of a new course of development of the Chinese society that is aimed at sustainable development, solving the environmental pollution issues, achieving harmony in the society. The Chinese authorities proposed a new course of 'ecological civilization' development. The authors analyze the issues that arise from the development of ecological civilization in China from the perspective of definition of the term 'ecological civilization' in the context of traditional Chinese culture, its relationship with traditional and modern understanding of the harmony and harmonious society, and development of legal regulations in the sphere of environmental protection. We provide the analysis of philosophical aspects of the emergence of ecological society, such as expansion of the Western anthropocentrism in the modern Chinese society, possibility of revival of ecological consciousness that is based on traditional Chinese culture, etc. The paper demonstrates the approach that was developed in the works of Chinese scholars regarding understanding of ecological civilization as a new stage of human society's development that comes after industrial society. In conclusion, the authors propose to consider that approach as a necessary civilizational choice that is to be taken by the Chinese society.
\end{abstract}

\section{Introduction}

Having embarked on achieving a path of 'Xiaokang' (a moderately prosperous society, society of a small welfare), the Chinese society started to prioritize economic development. As a result of such policy, there was a transition from the traditional agrarian society to the modern industrial society. Industrialization of the Chinese society is almost finished, especially in Central and Eastern parts of China. Urbanization is complemented by suburbanization. Small towns are being developed. In the context of the scientific program of development the decision was made to reduce the city-village differences. That is, to provide a village with 'urban look'. That means the development of infrastructure, improvement of a quality of social services, minimizing a gap between levels of income of rural and urban residents, increasing a cultural level of rural residents, etc. However, the previous program of development could not contribute to solving of one of the most pressing issue of the Chinese society - the issue of environmental pollution.

According to the WHO and Chinese Academy of Environmental Planning 350-500 thousand people die each year as a result of the air pollution in China [1]. That is a huge number. That is why, harmony between the society and nature is one of the most important measurements of the ecological society development in the modern concept of the Chinese society's development. The problem of developing of harmonious society in China is a problem of renewed understanding of social harmony, social justice, and social trust. However, effective ways of resolving the main contradictions in the society-nature system has not been found. The issue of future prospects of harmonious society developing seems to be problematic.

In the past two years, the slogan of 'developing of ecological civilization' has perhaps the most important place in the speeches of the President of China, Xi Jinping. The clause regarding 'ecological civilization was included in the chapter of the statute of the Congress of the Communist Party of China during the 18th Party Congress (November 8-14, 2012). In his report at the Congress the former President of China, Hu Jintao, called for 'spare no effort in order to preserve more farmland for farmers and to leave beautiful homeland with green fields, pure water, and blue sky for future generations' [2]. These words express a sense of 'environmental responsibility' of the Chinese authorities to future generations.

\section{Materials and methods}

The methodological basis of the research is a dialectical method that is being used for understanding of

\footnotetext{
a Corresponding author: baoyu2008@yandex.ru
} 
'traditional-modern' dichotomy as a unity that exists in an unstable balance of opposites. These opposites are characterized by not only struggle, but also mutual transition. The systematic approach allowed considering the object of study comprehensively, in its development and solidity. We formed our understanding of ecological civilization and its connection with harmonious society development by combining a historical-philosophical approach with the possibility of realistic verification of Chinese society's actual issues on the basis of historical, statistical, and empirical data.

Since the paper discusses the question of values, we develop an idea of the member of RAS, N.I. Lapin, that in the 21 century the fundamental values are human life, human dignity, and non-violence [3], non-violence between people, between people and society, between states, and between society and nature.

\section{Results and discussion}

\section{The concepts of 'harmony' and 'harmonious society' in the Chinese culture}

In the context of the Chinese spiritual culture, nonviolence correlates with a concept of 'harmony'. In the modern concept of Chinese society's development, 'harmonious society' means harmony between society and nature, an individual and society, an individual and other people, and, finally, between an individual and his/her inner world. The concept of harmonious society draws heavily on social ideals of the Chinese traditional spiritual culture. Category 'he' (和) - consent, harmony, friendship - is of great importance to the traditional culture of China. That is a basic principle of communication, basic rule of regulation of relations between people, between an individual and society, between states. Since ancient times, much attention was paid to social harmony as a basis of mutual understanding, conflict solving, cooperation, and mutual assistance. It is that culture of harmony that distinguishes Chinese tradition from Western culture.

Nowadays, Chinese scholars believe that it helps to overcome temptations of modern civilization and establish higher human civilization. We can say that this category presents a higher social ideal, at which the Confucian culture aims. Its essence is to coordinate all non-homogenous and on that basis to achieve a new harmonious unity. In addition, it is to create something new in the process of interaction of opposites.

\section{Inner harmony of the concept of 'ecological civilization'}

Modern condition of the Chinese society development dictate the need for transition from industrial society to something new - to ecological civilization. Here, China will be a pioneer. Nowadays, the Chinese society, probably, tries to feel the contours of the new future for all mankind. The concept of 'ecological civilization' is extremely harmonious in the context of the Chinese spiritual culture.
In regards to the category of civilization, in the Chinese language it is translated as '文明' (Wenming) and etymologically consists from two characters '文 culture and '明 - light. It is worth mentioning that in the Chinese culture that category has modern and traditional understanding. Famous Chinese calligrapher and culture expert Ouyang Zhongshi notes deep connection between the terms 'Wen' - culture, 'De' - morality, 'Hua' change, and 'He' - harmony. On the basis of an expression '五色成文而不乱' (in which 'Wen' is opposed to chaos, confusion) from the 'LiJi' canon, he argues in his interview: 'I think that 'Wen' reflects a desire for harmony, that is a harmony and prosperity' [4]. In general, the term 'Wen' is understood as something opposite to natural, human-made.

The second character '明' is translated as 'light', 'bright', but there is another meaning - 'knowledge', 'understanding'. 'DaXue' canon (8-3 centuries BC.) begins with the words:

大學之道
在明明德
在親民
在止於至善
Great teaching's Dao-way includes
Clarification of the light grace - De,
Becoming close with people,
And stop at the perfect goodness [5]

In 'Questions of Wang Yangming to the Great Teaching of (Daxue) (1527) it is made clear what is “明明德 (lightening of the light grace) [6]. In that essay Ming, era's eminent philosopher-neoconfucianist, develops a concept of 'onebodiness' or 'one body'. 'Great people believe the sky, earth and darkness of things to be as one body. They see the Middle Kingdom as one family, one man' [6]. Although a insignificant person's heart is overshadowed by passions and dizzied by selfishness, it is no different of a great person's heart. That is why 'lightening' is needed. Lightening '明' (Ming) means here inner understanding, revealing by a person of his/her nature that is characterized by empathy, compassion, and humanity.

The concept of the 'lightening of the light grace' includes ideas of harmony and 'onebodiness' of human and nature. 'His heart is not able to bear the sight of birds and animals piteously crying and trembling with fear. That is because his humanity forms a single whole with birds and animals, because they have got consciousness. When cutting down and destruction of plants and trees, his heart inevitably overflows with compassion and empathy. That is because his humanity forms a single whole with plants and trees, because they have got life force (vital spirit). At the sight of stone and tile destruction his heart certainly feels concern and regret. That is because his humanity forms a single whole with stone and tile. That is what is humanity [all that reduces into] sole body' [6].

In the ancient texts the terms 'Wen' and 'Ming' were sometimes used together. The canon 'Book of Changes' states '天下文明”, ‘文明以止人文也'. The last phrase affirms the existence of clear link between the term 'Wenming' 
and humanity. Using such traditional understanding, the term 'Wenming' can be translated not yet as 'civilization', but it means in fact 'enlightenment'.

It is impossible to build a society of social harmony without proper moral culture. The issue of social justice is crucial for harmonious society and ecological civilization. Because social harmony means a balance between interests of different social groups, between interests of present and future generations as well as between needs of society and nature. In Chinese culture, justice is closely link with the term 'sincerity' (诚言 'Chengxin). In ancient times, the categories 'Cheng' (sincerity, authenticity) and 'Xin' were used independently, but could be used interchangeably. In Chinese culture, 'Cheng' is first of all a philosophical category, and only then ethical.

In the treatise 'Zhongyong' (3-2 century BC), the problem of 'Cheng' is discussed in two aspects that identified two main directions of integration of this concept into Chinese culture:

1) 'Sincerity of Heaven' as a quality that is immanent to the world and realized itself in spontaneous perfection. Hence, there is the search for sincerity by the sage that would allow him to merge with the world

2) A quality of low that is aimed at maintenance of adequate social contact and could be gained in the process of inner-transformation under condition of pursuit of good. [7]

'Zhongyong' states that 'The one who reached the sincerity acts right without applying special efforts, and understands without making much effort. He reaches harmony with Dao easily' [8]. This philosophical statement means that the law of development of the Universe is to follow one's own nature. A person as a part of the Universe should follow his/her nature.

\section{Civilizational choice and values of the modern Chinese society}

The growth of ecological civilization is associated with a mode of production, people's way of life and their specific values. Chinese scholar Wu Shaoxia argues that 'The transition to ecological civilization is seen as irreversible global trend, as much as it was with the transition to agricultural civilization, and industrial civilization of human society'. It is noted that the development of ecological civilization is a complicated and complex project. It is based on a rejection of utilitarian concept of development, on a creation of a new concept of harmonious development of human and nature, on a development and improvement of environmental awareness of people [9]. All of that requires a following set of measures: adoption of relevant legislative acts that restrict and regulate excessive consumption.

In order to achieve that goal, the Chinese government not only proclaims respective slogans, but also improves current legislation on environmental protection and works on improving environmental situation in big cities, areas where there is a serious damage to nature. In recent years, more than 50 central administrative regulations, around 660 local government regulations and 800 national standards were adopted on environmental protection [1]. However, as many scholars argue, the effect of the laws was limited due to violations by the officials who were primarily interested in projects' economic efficiency or personal gain.

To improve that situation, a legal act known as document N12 'The Opinion of the Central Committee of The Communist Party of China and State Council on further promotion of ecological civilization's development' was adopted. That document systematically discusses measures on establishing standards, mechanisms and assessments that are aimed at realization of the goal declared in that document. Mechanisms mean new punishments for the officials who oppose ecological initiatives as well as various incentives for the officials who reject 'economic growth as the only criteria of governmental activity'. Thus, environmental violations will affect bureaucrat's career like a 'black mark'. The document also encourages public participation, including NGOs, in environmental governance, in the promotion of greater environmental transparency. That is an encouraging sign in the light of the crisis of social confidence that was caused by the strengthening of control over civil society [1].

Public concern in regards to pollution problems sometimes is manifested in the form of protests. In the end of October 2012, for instance, more than one thousand citizens of Nimbo, Zhejiang province, went to the streets to protest against municipal plan to expand a petrochemical plant. That demonstration forced local government to postpone the project's realization. That was not an only incident. Protests against industrial projects because of environmental issues in other cities were also successful [1]. However, many Chinese social scientists argue that following the law cannot replace an internal belief. The law is intended to regulate social relations but it does not have a task in achieving a harmony between the society and nature. We agree that only organic combination of law and morality can provide an ongoing development of the Chinese society in the development of ecological civilization.

Chinese scholars see the cause of the problem in a spread of anthropocentric worldview and values in the Chinese society according to that the nature is objectified and seen as means to achieve our goals.

No one doubts that the Chinese traditional values are a treasury that might provide a strong moral support for the development of ecological civilization. However, the Chinese do not forget about modern means to achieve certain goal. As it is well known, every year China spends tens of billions USD on scientific research. There is no choice but to await an outcome of such policies. Though hundreds of thousands of inventive patents are already registered on an annual basis. Most of the patents are in computer technologies, but patents in alternative methods of energy production (solar, wave) are on the second place. China has already become the world's largest producer of wind turbines and solar panels.

\section{Conclusion}


The Chinese society is facing a civilizational choice. Fundamental values of that choice are developed in the process of theoretical and practical search. To succeed in a creation of the new ecological civilization, the Chinese society will have to take a more radical approach moving away from the regime of 'excessive consumption' of capitalist society, because that regime is responsible for current global environmental crisis. However, there is reason to believe that a movement of the Chinese society towards ecological civilization as well as rich cultural heritage will contribute to the development of environmental awareness and ecological behavior of the population of that region and the Chinese society as a whole.

'The conception of building a harmonious society' has become a logical continuation of the 'conception of building the xiaokang society' [10]. The 'conception of ecological civilization has become a necessary continuation of both of them. All these concepts have become complementary. The idea of harmony (he) has strengthened the social orientation of the 'xiaokang' concept [10]. The concept 'ecological civilization' should help to promote co-evolution and harmony between human society and nature.

\section{Acknowledgment}

The paper was published within the state task project of the Ministry of Education and Science of the Russian Federation 'Comparative studies on social effects the development of mining industry of cross-border regions of Russia, Mongolia, and China', project N3433.

\section{References}

1. Zhihe Wang, Huili He, Meijun Pang, MR, 66, 3 (2014) http://monthlyreview.org/2014/11/01/theecological-civilization-debate-in-china/

2. S. Geall, Chinadialogue, Interpreting ecological civilization (part one) (2015) https://www.chinadialogue.net/article/show/single/e $\mathrm{n} / 8018$-Interpreting-ecological-civilisation-part-one-

3. N.I. Lapin, Voprosy Filosofii, 4, 1 (2015) http://vphil.ru/index.php?option=com_content\&task $=$ view\&id $=1137$

4. Zhongshi Ouyang, Xinhua, «Wen, de, hua, he - si ge zi shi zhonghua wenhua de jingshen, (2013) http://news.xinhuanet.com/comments/201303/07/c 114927739.htm

5. A.I. Kobzev, Arkhiv rossiiskoi kitaistiki, Izuchenie Daxue v Rossii i na Zapade, 2, 172-205 (2013)

6. A.I. Kobzev, Filosofiya kitajskogo neokonfucianstva, 488-499 (2002)

7. A.S. Martynov, Kitajskaya filosofiya. Enciklopedicheskij slovar' (2009)

8. Konfucianskii traktat Zhong yong. Perevody i issledovaniya, (2003)

9. Shaoxia $\mathrm{Wu}$, Journal of Jiangnan University (Humanities \& Social Sciences), Xia shengtai wenming: renlei wenming yanjinde biran xuanze, 2, 36-38 (2008)

D. Tsyrendorzhieva, O. Balchindorzhieva, RPTSS, 166, 670-674 (2015) 